УДК 658.821:676

СЕМЮК С.Є., Г.І. ГОЛОДЮК, ГУРГУЛА Н.М.

Луиький національний технічний університет

\title{
СУЧАСНИЙ СТАН І ПРОБЛЕМИ УКРАЇНСЬКОГО РИНКУ ЦЕЛЮЛОЗНО-ПАПЕРОВОЇ ПРОДУКЦІї
}

\author{
СЕМЮК С.С., ГОЛОДЮК Г.И., ГУРГУЛА Н.Н.
}

Луичкий национальный технический университет

\section{СОВРЕМЕННОЕ СОСТОЯНИЕ И ПРОБЛЕМЫ УКРАИНСКОГО РЫНКА ЦЕЛЛЮЛОЗНО-БУМАЖНОЙ ПРОДУКЦИИ}

\author{
S. Semyuk, G.Golodyuk, N. Gurgula \\ Lutsk national technical university
}

\section{CURRENT SITUATION AND PROBLEMS OF THE UKRAINIAN PULP AND PAPER MARKET}

\section{https://doi.org/10.36910/6775-2310-5283-2020-13-18}

Мета. Огляд сучасного стану ринку целюлозно-папрерової про продукції в Україні дослідження основних тендениій та перспектив розвитку.

Методика. Під час проведення досліджень використано аналітичні та статистичні методи обробки даних. B процесі роботи використовувались дані Державного комітету статистики, матеріали статей та Інтернет - конференцій з даної теми дослідження. Грунтується на методах аналізу, синтезу та узагальнення

Результати. Встановлено, щзо вітчизняна ичелюлозно-паперова промисловість займає досить малу частку на українському ринку, необхідно розширити асортимент паперу для друк, створити конкуренцію імпортній продукиї. Слабкий розвиток виробництва первинних напівфабрикатів (целюлози і деревної маси) поставив галузь у повну залежність від імпорту ијєї сировини $і$ змушує ї̈ орієнтуватись на виготовлення паперу з вторинної сировини - макулатури. Технічний стан целюлозно-паперової галузі суттєво застарів.

Все це впливає на зменшення випуску білих високоякісних видів паперу та невисокій якості продукиї.На сьогодні ринок України представлений в основному іноземною продукцією. Вітчизняна ж, або взагалі відсутня, або обсяги ї̈ споживання є незначними. Особливо критичною є ситуація з наповненням ринку вітчизняним папером для друку, в зв'язку його низькою якістю, слабкою конкурентоспроможністю та обмеженістю видового та внутрішньовидового асортименту.

Наукова новизна. Проаналізовано стан ринку в Украйні та проведено дослідження основних виробників целюлозно-паперових виробів, експортно-імпортні операції країн 
контрагентів.

Практична значимість. Аналіз тенденцій розвитку ринку целюлозно-паперових виробів в Україні дає можливість використання їх при подальших дослідженнях.

Ключові слова: целюлоза, макулатура, целюлозно-паперова промисловість, папір для друку, зошити, санітарно-гігієнічні виробів, експорт, імпорт.

\section{Поставка проблеми у загальному вигляді та її зв'язок із важливими} науковими та практичними завданнями. Не зважаючи на бурхливий розвиток комп'ютерних технологій та інших засобів передачі інформації, які зайняли своє місце на ринку комунікацій, i безперечно створюють конкуренцію паперу, все ж споживання його у світі не лише не зменшилось, а навіть збільшилось.

Сьогодні на світовому ринку паперу задіяні величезні суми грошових коштів, і зважаючи на те, що споживання даної продукції у світі щороку зростає, то цілком логічним буде припустити, що тенденція до зростання ємності ринку збережеться і в майбутньому.

Взагалі, якщо проаналізувати дані за споживанням паперової продукції на душу населення в світі, то виявляється певна закономірність: чим більше споживання - тим вищий загальний рівень життя. Для прикладу: у США споживається 336 кг даної продукції на душу населення в рік, у Японії - 270 кг, Великобританії - 260 кг, Німеччині - 255 кг, Польщі - 55 кг. В Україні за 2018 рік споживання становило 32,2 кг/люд. Ця цифра настільки відрізняється від вищенаведених, що просто не хочеться вірити в те, що тут може простежуватись якась закономірність. Як можна пояснити настільки низький показник? Звичайно, можна було б сказати, що Україна 3 часу здобуття незалежності переживала нелегкі часи, і що на фоні показників інших галузей ця цифра виглядає цілком природною. Так, з покращанням загального рівня життя, збільшенням доходів населення безперечно зросте споживання паперу. За останні 3-4 роки простежується певна тенденція до зростання, що підтверджує дане твердження.

Виявляється доля вітчизняної продукції у споживанні складає лише близько 50 \%, і в основному за рахунок пакувального картону та туалетного паперу. Щодо так званих «культурних» видів паперу, в тому числі і паперу для друку, то тут імпорт складає більше 90 \%. Щорічно десятки комерційних фірм витрачають більше ста мільйонів доларів на імпорт того ж паперу для друку, таким чином, опосередковано інвестуючи іноземних виробників. Наші ж підприємства все більше і більше втрачають позиції на даному сегменті 
ринку паперу. До того ж вітчизняна продукція в основному програє за якістю своїм закордонним аналогам, а асортимент тих видів паперу для друку, що випускаються є досить обмеженим. Виробництво окремих видів на сьогодні або зовсім відсутнє, або ж вони випускається в такій кількості, що їх можна не брати до уваги.

Аналіз основних досліджень, у яких започатковано вирішення проблеми. Целюлозно-паперова промисловість і ринок картонно-паперової продукції передбачає одним із найважливіших напрямків розвитку паперової галузі створення в інфраструктурі діючих підприємств з виробництва нових, високорентабельних видів продукції для задоволення потреб внутрішнього споживчого ринку високоякісними видами паперу та картону та максимальної заміни імпортної продукції вітчизняною.

Результати теоретичних досліджень паперової продукції викладено в роботах вітчизняних та закордонних науковців Путінцева С.В., Байдакова Л.І., Передрій O.I., Примакова С.П., Труша М.М.. Дослідження проблеми ідентифікації паперу та виробів 3 нього Глушкової Т.Г., Барабаш С., Вилкова С.А.

Цілі статті. Проаналізувати сучасний ринок целюлозно-паперових виробів в Україні, динаміку імпорту та експорту, визначити основні тенденції та перспективи розвитку.

Об'єкт дослідження. Об'єктом дослідження є світовий та вітчизняний ринок целюлозно-паперових виробів.

Методи дослідження. У ході проведення дослідження використано аналітичні та систематичні методи обробки даних.

Виклад основного матеріалу дослідження з повним обгрунтуванням отриманих наукових результатів. На сьогоднішній день в галузі функціонує 100 підприємств, 3 яких 22 целюлозно-паперові, целюлозно-картонні, паперово-картонні комбінати та заводи. До складу галузі входять також наукова проектна організація Науково-дослідний інститут паперу (УкрНДІП) і Інститут проектування підприємств ЦПП «Укргіпромбум».

Технічний стан галузі характеризується значним старінням основних фондів. Більша частина підприємств існує з 19 або початку 20 століття. Лише 5 з них були побудовані після 1945 року і 4 - після 1960. На багатьох $з$ них продовжується експлуатуватись обладнання, отримане після війни по репарації, яке в наступні роки піддавалось багаторазовим модернізаціям i реконструкціям. Основна частина обладнання підлягає реконструкції або заміні, оскільки експлуатується 40 і більше років, і відрізняється великим 
фізичним і моральним зносом. Загальна встановлена потужність паперо- i картоновиробних машин підприємств України становить біля 1 млн. тон паперу та картону, що може забезпечити виготовлення 20 кг цієї продукції на одного мешканця. Фактичне завантаження цих потужностей в 2017 році ледве перевищило 40\%. Основна причина - недостатнє забезпечення виробництва сировинними ресурсами (целюлозою, деревною масою, макулатурою) [1].

Виробництво термомеханічної маси в Україні відсутнє. Сдиним виробником білої (дефіброваної) деревної маси є Жидачівський целюлознопаперовий комбінат.

В Україні також відсутні потужності 3 переробки у целюлозу чи механічну масу недеревних видів волокнистої сировини (соломи, коноплі або інших однорічних рослин).

Слабкий розвиток виробництва первинних напівфабрикатів (целюлози і деревної маси) поставив галузь у повну залежність від імпорту цієї сировини і змушує їі орієнтуватись на виготовлення таких видів паперу і картону, які виробляються 3 вторинної сировини - макулатури. Однак, через різке зниження рівня споживання паперово-картонної продукції за останні роки (по відношенню до 2019 р. більш ніж в 3 рази) скоротився і ресурс макулатури (рис. 1).

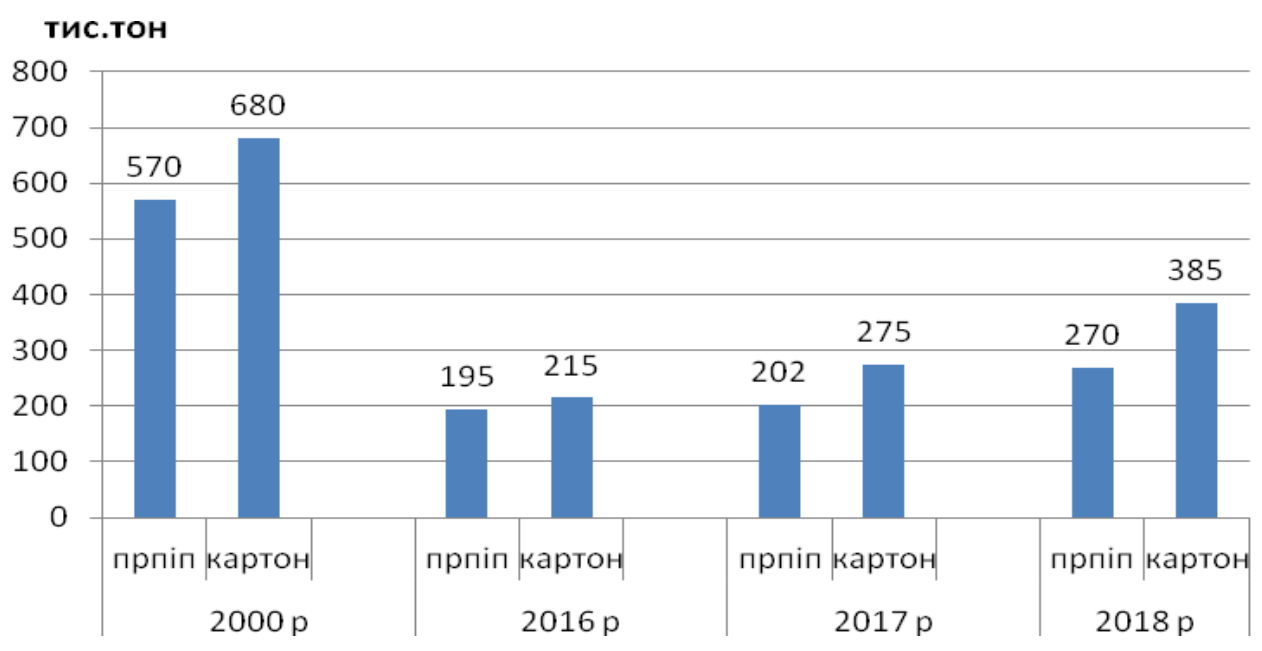

\section{Рис. 1. Динаміка забезпечення виробництва паперу та картону основною сировиною (макулатурою) за роками, тис. тонн}

В 2017 році iї було заготовлено лише 271 тис. тон, в той час як встановлені на підприємствах галузі потужності здатні переробити більше 700 тис. тон макулатури в рік. Ці обставини ускладнюють проблему забезпечення 
галузі сировиною і змушують підприємства вишукувати шляхи закупівлі по імпорту не лише целюлози, але і макулатури.

На рис 1. яскраво відображена ситуація динаміки виробництва основних видів целюлозно-паперової промисловості за останні роки. У 2018 році виготовлено продукції значно менше, ніж в 2000, особливо паперової.

Але все ж можна простежити тенденцію до нарощування обсягів виробництва за період з 2000 по 2018 роки.

Переважання макулатури у загальному балансі сировини для потреб паперово-картонного виробництва диктує і відповідну специфіку: зменшення випуску білих «культурних» видів паперу при невисокій якості продукції [5].

Проте в галузі є значні потужності 3 переробки паперу та картону у вироби: картонну тару, шпалери, зошити, споживчу тару, паперово-білові товари тощо (табл.1).

Таблиця 1.

Потужності виробництва станом на 01.01.17 [20]

\begin{tabular}{|l|l|}
\hline \multicolumn{1}{|c|}{ Назва виробу } & \multicolumn{1}{c|}{ Об’єм виготовлення } \\
\hline Потужності по гофротарі & 600 млн. м \\
\hline Шпалери & 190 млн. умовних кусків \\
\hline Зошити & 900 млн. штук \\
\hline Туалетний папір & до 280 млн. штук споживчих рулончиків \\
\hline
\end{tabular}

Особливо слід відмітити суттєве зростання виробництва картону та транспортної тари. На сьогодні об’єм товарної продукції галузі в діючих цінах складає біля $1,1 \%$ від валового національного продукту, що є значно нижче від можливого рівня [2].

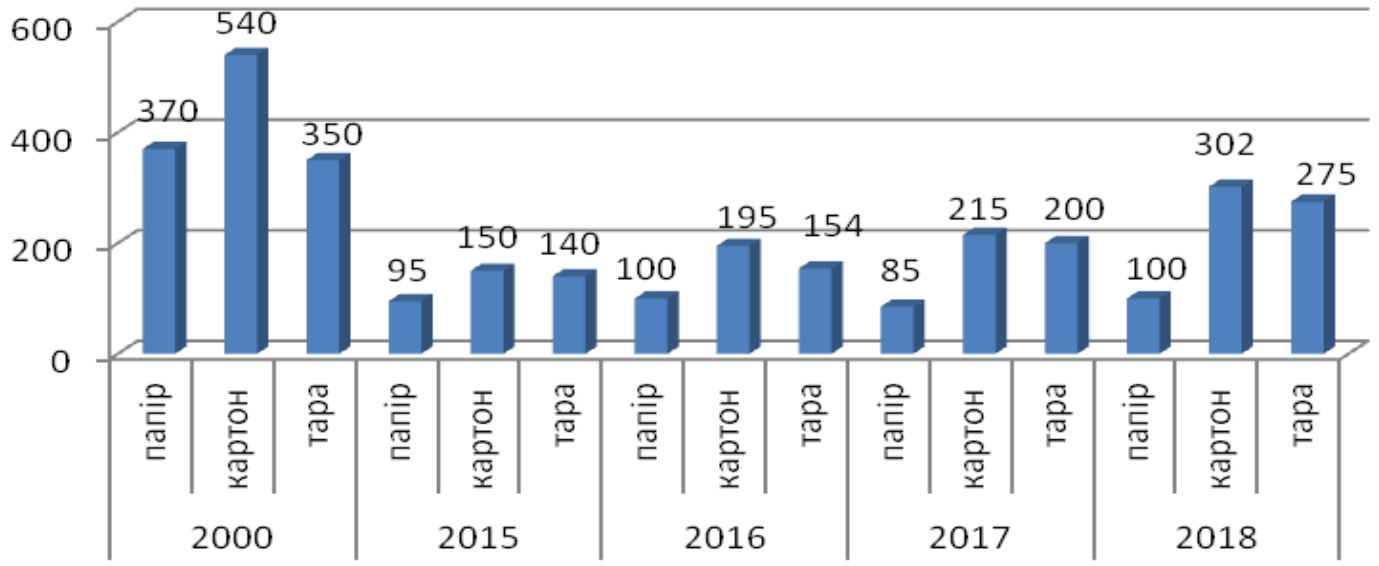

Рис. 2. Динаміка виробництва основних видів целюлозно-паперової промисловості за останні роки, тис, тонн 
На рис. 2 відображена динаміка виробництва основних видів целюлознопаперової промисловості за останні роки.

Взагалі, нинішній стан целюлозно-паперової промисловості України не відповідає потребам ії економіки, культури, освіти. За рівнем споживання на душу населення країна займає одне 3 останніх місць в Європі. Виходячи 3 цього, галузь об'єктивно потребує свого розвитку. У таблиці 2 наведено результати роботи підприємств галузі за 2018 рік.

Таблиця 2.

\section{Підсумки роботи целюлозно-паперових підприсмств України за 2018 рік}

\begin{tabular}{|c|c|c|c|c|c|c|}
\hline \multirow[t]{2}{*}{ Підприємства } & \multicolumn{3}{|c|}{$\begin{array}{c}\text { Товарна продукція в } \\
\text { порівняльних цінах, } \\
\text { тис.грн. }\end{array}$} & \multicolumn{3}{|c|}{$\begin{array}{c}\text { Товарна продукція в } \\
\text { діючих цінах, } \\
\text { тис.грн. }\end{array}$} \\
\hline & $2018 p$ & $2017 p$ & \%до 2017 & $2018 p$. & $2017 p$. & \%до 2017 \\
\hline 1 & 2 & 3 & 4 & 5 & 6 & 7 \\
\hline Київський КПК & 332383 & 287898 & 115,5 & 323495 & 287321 & 112,6 \\
\hline Рубіжанський КТК & 195569 & 287898 & 111,6 & 221235 & 184402 & 120,0 \\
\hline Жидачівський ЦІЖ & 218673 & 175308 & 128,3 & 208306 & 170828 & 121,9 \\
\hline Понінківський КПК & 19237 & 170414 & 109,0 & 12573 & 12307 & 102,2 \\
\hline Малинська ПФ & 52139 & 17654 & 132,8 & 48999 & 39440 & 124,2 \\
\hline Ізмаїльський ЦКК & 44342 & 39254 & 184,3 & 43538 & 13598 & 320,2 \\
\hline Дніпропетровська ПФ & 40888 & 24056 & 121,5 & 6152 & 8047 & 76,5 \\
\hline Львівкартонпласт & 5313 & 33665 & 237,4 & 5313 & 2238 & 237,4 \\
\hline Всього по холдингу & 908544 & 2238 & 121,1 & 869611 & 718181 & 121,1 \\
\hline Корюківська ПТФ & 267251 & 230568 & 115,9 & 265825 & 228975 & 116,1 \\
\hline Кохавинська ПФ & 19330 & 15175 & 127,4 & 16423 & 14371 & 114,3 \\
\hline Славутсько-Пол. ПФ & 7840 & 10130 & 77,4 & 7678 & 9618 & 79,9 \\
\hline Миропольська ПФ & 8144 & 5366 & 151,8 & 4053 & 3508 & 115,7 \\
\hline Моквинська ПФ & 5338 & 4308 & 123,9 & 2336 & 4540 & 51,5 \\
\hline Роганська КФ & 7053 & 4754 & 148,4 & 6509 & 2767 & 235,2 \\
\hline Россошська ПФ & 2029 & 3013 & 67,3 & 1274 & 2209 & 57,7 \\
\hline Київська ФТП & 2084 & 2151 & 96,9 & 1969 & 2010 & 98,0 \\
\hline Чижевська ПФ & 307 & 1703 & 18,0 & 307 & 1703 & 18,0 \\
\hline «Крон екс Україна» & 3460 & 1368 & 88,0 & 2057 & 1567 & 101,6 \\
\hline $\begin{array}{l}\text { Рахівська КФ ТОВ «Таврія- } \\
\text { Папір» }\end{array}$ & 1061 & 3933 & 105,2 & 4053 & 2025 & 45,8 \\
\hline Всього по галузі & & 10339 & & & 9925 & \\
\hline
\end{tabular}

Суттєве нарощування об’ємів випуску галузевої продукції можливе лише після подолання відставання галузі, викликаного низьким технічним рівнем технологічного обладнання підприємств, гострим дефіцитом волокнистої 
сировини i капіталовкладень в розвиток галузі.Внаслідок цього основним напрямком розвитку целюлозно-паперової промисловості України за своєю гостротою на найближчу перспективу залишається проведення реконструкції і модернізації паперо - та картоновиробних машин, удосконалення технологічних схем виробництва, використання нових більш ефективних хімікатів і технологічних добавок для створення умов підвищення якості i конкурентоспроможності виготовленої продукції.

Відсутність розвинутої сировинної бази і викликаний цим дефіцит основних волокнистих напівфабрикатів - целюлози i деревної маси, $\epsilon$ головною причиною, що стримує нарощування обсягів випуску паперу, картону і виробів 3 них. Хоча, певні запаси потенційної сировини в нас $є$ (табл.3).

Таблиця 3

\section{Дані лісосировинної бази України}

\begin{tabular}{|l|c|}
\hline Лісосировинна база України & Обсяги лісосировинної бази \\
\hline Площа лісів & 9,4 млн.га \\
\hline Запас деревини & 1,8 млрд.м ${ }^{3}$ \\
\hline Щорічний приріст & біля 35 млн. м ${ }^{3}$ \\
\hline Щорічний обсяг заготівлі & 10,5 млн. м \\
\hline
\end{tabular}

Нинішня лісосировинна база України гарантовано забезпечить досягнення запланованої потужності по випуску целюлози і деревної маси необхідною деревною сировиною [1].

Стан ринку целюлозно-паперової промисловості оцінюється за загальноприйнятими у світі показниками споживання картонно-паперової продукції на душу населення. За обсягами виробництва паперу на душу населення світовими лідерами є країни Північної Свропи, Канада та Австрія. При цьому Канада спеціалізується на виробництві газетного паперу, а Фінляндія, Швеція, Норвегія - офісного. У всіх розвинутих країнах виробляють багато пакувального паперу [3]. Аналіз ринку целюлознопаперової продукції [4] свідчить, що за останні 10-15 років найбільш масовими іiі видами $\epsilon$ папір для друку та таропакувальні-композиційні матеріали. 3400 млн.т картоно-паперової продукції близько 41\% становить таропакувальні матеріали, 42\% - папір для друку (11\% - газетний, 31\% - білі види) та 6\% санітарно-гігієнічний папір (рис.3). 

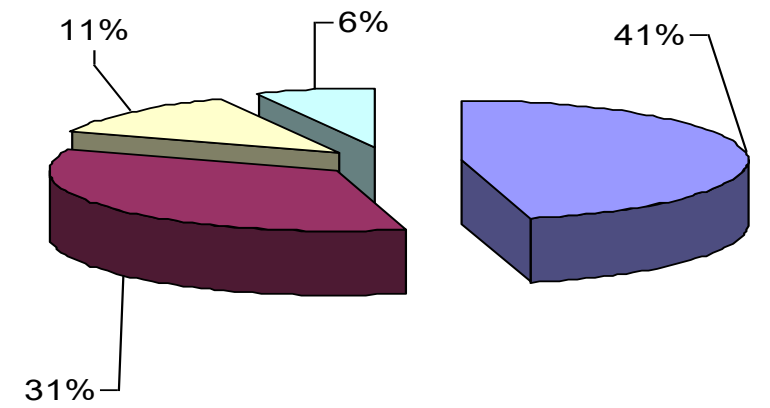
$\square$ Таропакувальний матеріал
Білі види паперу для друку
$\square$ Газетний папір
$\square$ Санітарно- гігієнічний папір

\section{Рис. 3. Виробництво целюлозно-паперової продукції}

Споживання паперу та картону в Україні на одну особу 32,2 кг на рік, що майже вдвічі нижче від рівня середньосвітового споживання, який становить 70 кг на рік [5].

За цим показником Україна займає одне з останніх місць в Європі. На сьогодні ємність внутрішнього споживчого ринку оцінюється в межах 650-700 тис. тон [2]. Частка вітчизняного товаровиробника на українському ринку складає лише 40\%. Причому обсяг імпорту з певних видів паперової продукції становить більше $90 \%$ (табл. 4).

Світовий обсяг виробництва паперу та картону - понад 250 млн.м ${ }^{3}$, близько 30\% якого припадає на письмовий і друкований папір, $15 \%$ - газетний папір, 55 \% - на інші сорти для упакування, технічних і санітарних потреб [2].

Таблиця 4

\section{Структура експорту продукції за 2017 рік по 48-й групі УКТ ЗЕД}

\begin{tabular}{|c|l|c|}
\hline \multirow{2}{*}{ Код УКТ ЗЕД } & \multicolumn{1}{|c|}{ Назва групи } & $\begin{array}{c}\%, \text { до підсумку } \\
\text { варт, вираженні }\end{array}$ \\
\hline 4811 & Папір та картон, просочені гудроном, пластмасою тощо & 31,0 \\
\hline 4814 & Шпалери & 23,9 \\
\hline 4819 & Ящики, коробки & 13,5 \\
\hline 4810 & Папір та картон пігментовані & 5,9 \\
\hline 4818 & Вироби санітарно-гігієнічні & 2,9 \\
\hline 4804 & Крафт-картон & 1,9 \\
\hline 4802 & Папір для друку та письма & 1,6 \\
\hline 4801 & Папір газетний & 0,9 \\
\hline Інші & & 6,9 \\
\hline
\end{tabular}

Протягом останніх 2,5 років структура імпорту пігментованого паперу за країною ії походження практично не змінювалась. Найбільшу питому вагу в загальному об’ємі імпорту в Україну займає пігментований папір, виготовлений в Фінляндії (близько 40\%) (рис. 4,5). 


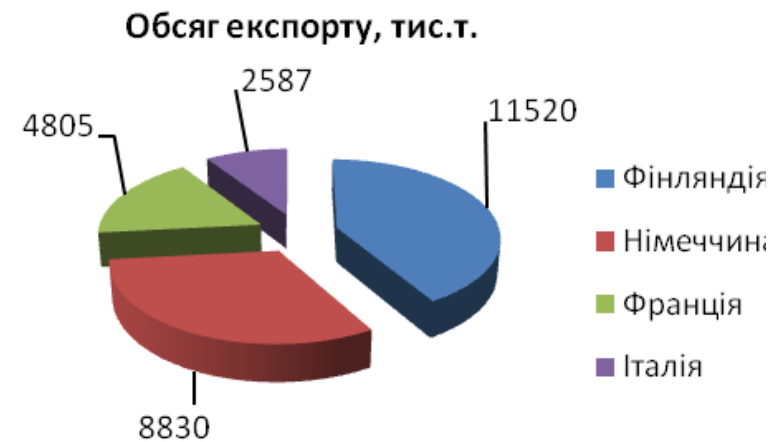

Рис. 4. Обсяги основних світових експортерів паперової продукції
Обсяги імпорту, тис.т.

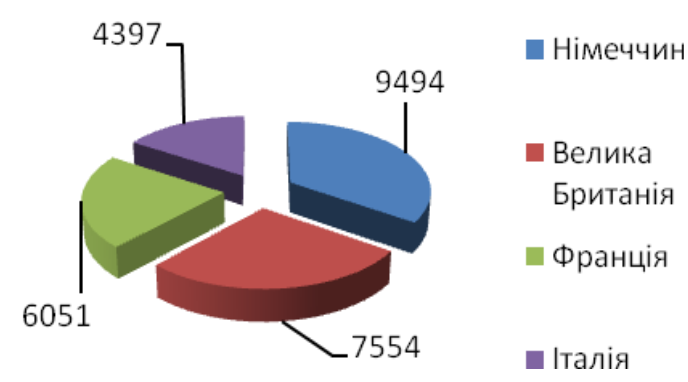

Процес глобалізації останніх років суттєво скоротив кількість основних постачальників пігментованого паперу в Україну. Чотири світових гіганти покривають сьогодні майже весь ринок пігментованого паперу - Stora-Enso (Швеція - Фінляндія), два фінських гіганти М-геа1 (що об’єднав недавно таких крупних виробників пігментованого паперу, як Metsa-Serla, Modo, Zanders i UPM-Kymmene), a також крупний європейський виробник 3 південноафриканським корінням - концерн Sappi. В останні роки на ринку України з'явивсь так званий легкопігментований папір (відрізняється від пігментованого масою нанесеного покриття) виробництва Neusiedler SCP Ruzomberok. Отже, найближчим часом можна сподіватись на те, що на ринку України з'явиться вітчизняна, конкурентоспроможна продукція.

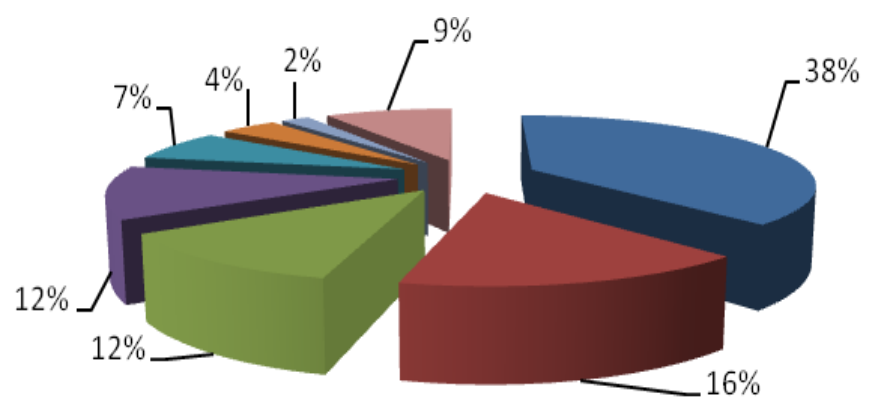

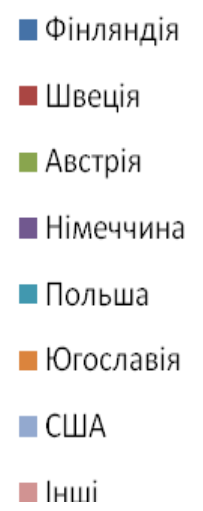

Рис. 6. Структура імпорту крейдованого паперу за країнами-імпортерами

Щодо газетного паперу, то його споживання у світі за 2017 році склало 98 тис. тон, 3 них імпортного - 75,5 тис. тон на суму 33,9 млн. дол. Частка українського виробника у спожитій продукції - 23\% [2]. За даними Державного комітету статистики України серед імпортованого газетного 
паперу 92\% припадає на Фінлядію, Польщу, Іспанію.На сьогодні в Україні працює три підприємства, що можуть здійснювати випуск газетного паперу: Жидачівський ЦПК, Понінківський КІЖ і Дніпропетровська ПФ. Але Понінківський КІЖ виготовляє газетний папір в невеликих кількостях (у 2017 році - 831 тона), а Дніпропетровська ПФ на даний час газетний папір не випускає. Головним постачальником вітчизняного газетного паперу на ринок України є Жидачівський КІЖ - 30 тис. тон на рік [2]. Споживання паперу для друку та письма в 2017 році склало 72 тис. тон. Частка українського виробника - 6,5\%. Імпорт цієї групи збільшився в 2017 році на 20 тис. тон у порівнянні з 2017 роком і склав 67,3 тис. тон на суму 38,9 млн. дол. США. Середня ціна 578 дол. за тону. Структура імпорту паперу для друку та письма відображена на рис.7.

Значно скоротився імпорт зошитів - на 27,5\%. В 2016 році в Україну було ввезено 8,3 тис. тон на суму 7,5 млн. дол., а в 2017 році - 6,1 тис. тон на суму 1,8 млн. дол [10]. Таке скорочення імпорту відбулось внаслідок захисних заходів, а саме, було введено 25\% мито на імпорт зошитів.

Імпорт зошитів по об'єму скоротився у 2017 році проти 2016 на 2,2 тис. тон (26,5\%), а за ввізними декларованими цінами - на 5,7 млн. дол. США (76\%). Середня ввізна ціна у 2016 році була 904 дол. за тону, а у 2017 році 298 дол. за тону. Але не дивлячись на зменшення імпортерами ціни, заходи по захисту вітчизняного виробника все ж мали значний ефект - ріст власного виробництва зошитів у 2017 році склав $180 \%$. В результаті доля українського виробника на ринку зошитів у 2017 році склала 52,4\% проти 38,5 в 2016 році.
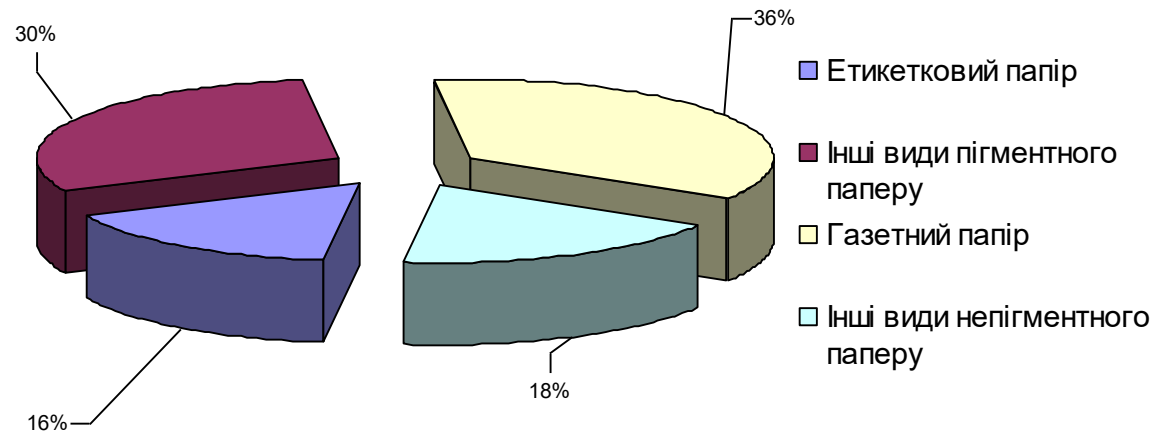

\section{Рис. 7. Структура імпорту паперу для друку та письма за країнами- імпортерами}

Санітарно-гігієнічних виробів у 2017 році імпортовано на 33,3 млн. дол. У тому числі дитячих пелюшок і аналогічних виробів (підгузників) - на 31,5 млн. дол. (94,6\%), туалетного паперу - 0,3 млн. дол. (0,9\%), інших (серветки, паперові носові хустинки, рушники тощо) - 4\% [2]. Імпорт паперу-основи для 
шпалер у світовому масштабі склав у 2017 році 38,7 тис. тон (25,2 млн. дол.) [3]. Шпалер в Україну імпортовано у 2017 році 10,3 тис. тон на суму 9,9 млн. дол.; 5,4 тис. тон завезено з Білорусії на суму 7,1 млн. дол. (середня ввізна ціна за тону шпалер -1315 дол. США) [2].

Слід зазначити, що асортимент і якість вітчизняних шпалер постійно покращується і виходить на рівень вимог європейських стандартів. Щодо експорту, то тут слід сказати, що обсяги його є незначними.

Експорт паперової продукції здійснюється в основному в країни Африки, Азії за рахунок низької ціни, яка в свою чергу викликана здебільшого низької якістю. Тобто, поки що про Україну, як про експортера паперової продукції говорити не доводиться.

Висновки та перспективи подальших досліджень. Проаналізувавши вище зазначені дані по обсягах і структурі ринку можна констатувати наступну головну проблему українського ринку паперу для друку - засилля іноземної продукції. Дана проблема зумовлена такими причинами: низькою конкурентоспроможністю вітчизняної продукції та якістю порівняно 3 iï іноземними аналогами, відсутністю сировинної бази у достатній кількості, сучасно обладнаних підприємств целюлозно-паперової промисловості.

Підбиваючи підсумки, необхідно зазначити той факт, що обсяги внутрішнього споживчого целюлозно-паперового ринку зростають, а за умови покращення загальної економічної ситуації він може зрости у декілька разів.

Тобто, перспективи розвитку ринку целюлозно-паперової продукції $\epsilon$, причому виглядають вони досить реальними. Тому важливо, щоб ті ніші ринку, які можуть бути насичені продукцією вітчизняних виробників, але на яких зараз домінуе імпортна продукція, все таки були заповнені конкурентоспроможними вітчизняними товарами.

Основним напрямом розвитку вітчизняних підприємств целюлознопаперової промисловості на найближчу перспективу залишається здійснення реконструкції і модернізації діючих машин, що виробляють папір і картон, удосконалення існуючих технологічних схем виробництва картоннопаперової продукції, впровадження нових, ефективніших хімікатів і технологічних добавок з метою підвищення якості готової продукції.

Треба також очікувати прискореного розвитку технологій, пов'язаних із використанням природних місцевих ресурсів, зокрема 3 переробкою соломи, вільний ресурс якої в Україні достатній. 


\section{Список використаних джерел}

1. Концепція загальнодержавної цільової програми розвитку цклюлозно-паперової промисловості України та вітчизняного ринку картонно-паперової продукції на період 2020 року [Електронний ресурс] / оф.сайт Міністерства промислової політики України. Режим доступу. http://www.kmu.gov.ua/industru/ control/uk/publish/article.

2. Офіційний сайт асоціації «Укрпапір» [Електронний ресурс] / оф.сайт Режим доступу. http://www.ukrpapir.org/nevs.phip.

3. Сумарний обсяг імпорту та експорту окремих груп товарів за кодами ТНЗЕД [Електронний ресурс] / оф.сайт Державної митної служби України - Режим доступу. http://www.kmu.gov.ua/industru/ control/uk/publish/article.

4. Путінцева С.В.Сучасний стан і проблеми світового та українського ринків целюлозно-паперової продукції // Вісник Херсонського національного технічного університету. 2016. №1. С. 126-130.

5. Пріоритети розвитку вітчизняної целюлозно-паперової промисловості [Електронний ресурс] / за даними сайту Урядовий портал. - Режим доступу. htpp: www.kmu.gov.ua/contral/poblisit/article?art_id=91605985.

\section{References}

1. Kontseptsiia zahalnoderzhavnoi tsilovoi prohramy rozvytku tskliulozno-paperovoi promyslovosti Ukrainy ta vitchyznianoho rynku kartonno-paperovoi produktsii na period 2020 roku [Elektronnyi resurs] / of.sait Ministerstva promyslovoi polityky Ukrainy. - Rezhym dostupu. http://www.kmu.gov.ua/industru/ control/uk/publish/article.

2. Ofitsiinyi sait asotsiatsii «Ukrpapir»[Elektronnyi resurs] / of.sait Rezhym dostupu. http://www.ukrpapir.org/nevs.phip.

3. Sumarnyi obsiah importu ta eksportu okremykh hrup tovariv za kodamy TNZED [Elektronnyi resurs] / of.sait Derzhavnoi mytnoi sluzhby Ukrainy - Rezhym dostupu. http://www.kmu.gov.ua/industru/ control/uk/publish/article.

4. Putintseva S.V. Cuchasnyi stan i problemy svitovoho ta ukrainskoho rynkiv tseliuloznopaperovoi produktsii // Visnyk Khersonskoho natsionalnoho tekhnichnoho universytetu. 2016. №1. S. 126-130.

5. Priorytety rozvytku vitchyznianoi tseliulozno-paperovoi promyslovosti [Elektronnyi resurs] / za danymy saitu Uriadovyi portal. - Rezhym dostupu. htpp: www.kmu.gov.ua/contral/poblisit/article?art_id=91605985.

Цель. Обзор современного состояния рынка цุеллюлозно-бумажной продукции в Украине исследования основных тенденций и перспектив развития.

Методика. При проведении исследований использованы аналитические и статистические методы обработки данных. В прочессе работы использовались данные Государственного комитета статистики, материаль статей и Интернет - конференций по данной теме исследования. Основывается на методах анализа, синтеза и обобщения.

Результаты. Установлено, что отечественная иеллюлозно-бумажная промышленность занимает довольно малую долю на украинском рынке, необходимо расширить ассортимент бумаги для печати, создать конкуренщию импортной продукции. Слабое развитие производства первичных полуфабрикатов (иеллюлозы и древесной массы) поставил отрасль в полную зависимость от импорта этого сырья и заставляет ее 
ориентироваться на изготовление бумаги из вторичного сырья - макулатуры. Техническое состояние целлюлозно-бумажной отрасли существенно устарел.Все это влияет на уменьшение выпуска бельх высококачественных видов бумаги и невысоком качестве продукиии.На сегодня рынок Украины представлен в основном иностранной продукиией. Отечественная же, или вообще отсутствует, или объемы ее потребления незначительны. Особенно критической ситуация с наполнением рынка отечественным бумагой для печати, в связи его низким качеством, слабой конкурентоспособностью $и$ ограниченностью видового и внутривидового ассортимента.

Практическое значение. Анализ тенденций развития рынка целлюлозно-бумажных изделий в Украине дает возможность использования их при последуюших исследованиях.

Ключевые слова: ичеллюлоза, макулатура, целлюлозно-бумажная промышленность, бумага для печати, тетради, санитарно-гигиенические изделий, экспорт, импорт.

Goal. Overview of the current state of the pulp and paper market in Ukraine for the study of major trends and development prospects.

Method. Analytical and statistical methods of data processing were used during the research. In the course of the work the data of the State Committee of Statistics, materials of articles and Internet conferences on this topic of research were used. It is based on methods of analysis, synthesis and generalization.

Results. It is established that the domestic pulp and paper industry occupies a rather small share in the Ukrainian market, it is necessary to expand the range of paper for printing, to create competition with imported products. The weak development of the production of primary semifinished products (pulp and pulp) has made the industry completely dependent on the import of this raw material and has made it oriented towards the production of recycled paper - waste paper. The technical condition of the pulp and paper industry is substantially outdated.All this has the effect of reducing the production of white, high quality paper and poor product quality. Today the Ukrainian market is represented mainly by foreign products. Domestic is either absent or its consumption is negligible. Particularly critical is the situation with filling the market with domestic printing paper, due to its poor quality, poor competitiveness and limited species and intraspecific range.

Practical meaning. Analysis of trends in the market of pulp and paper products in Ukraine makes it possible to use them in further research.

Keywords: pulp, waste paper, pulp and paper industry, printing paper, exercise books, hygiene products, exports, imports.

Стаття рекомендована до публікащії доктором технічних наук, професором Луиьького НТУ Байдаковою Л.І. Дата надходження в редакиію 11.12.2019 р. 